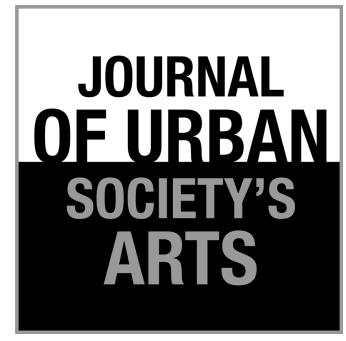

Volume 2 Nomor 2,

Oktober 2015: 63-79

\section{Empat Koreografer Minangkabau: Dibaca dalam Teks Matrilineal dan Patrilineal}

\section{Surheni}

Jurusan Tari, Fakultas Seni Pertunjukan,

Institut Seni Indonesia Padangpanjang

E-mail: surfabiokenji@gmail.com; HP: 081374018743

\begin{abstract}
ABSTRAK
Artikel ini membahas empat koreografer Minangkabau yaitu Gusmiati Suid, Huriah Adam, Syofyani Bustamam, dan Syahril dari perspektif matrilineal dan patrilineal. Teks matrilineal tidak hanya dipandang dari sisi genealogis, tetapi juga dari sudut pandang budaya. Berdasarkan penelitian disimpulkan bahwa partisipasi perempuan di luar wilayah domestiknya terbias dalam seni tari. Perempuan tidak dinantikan hanya untuk menyemarakkan dengan tebaran pesona keindahan ragawi. Ia mampu menjadi sumber ide dan tema, pelaku, pencipta, pengatur, dan penyelenggara, atau sarana mobilitas seni pertunjukan. Keempat koreografer lahir dan dibesarkan di Minangkabau akan tetapi berkiprah di tiga wilayah yang berbeda. Gusmiati Suid di Jakarta, Huriah Adam di Sumatera Barat, Syofyani di Padang, dan Syahril di Padangpanjang. Sebagai koreografer yang lahir dan dibesarkan dalam kultur Minangkabau tentu keempat koreografer ini ikut merasakan betapa dilematis posisi perempuan dalam masyarakat Minangkabau.
\end{abstract}

Kata kunci: koreografer, Minangkabau, matrilineal, patrilineal

\begin{abstract}
The Four Choreographers of Minangkabau: Being Read in Matrilineal and Patrineal Text. This article discusses about four choreographers of Minangkabau, among others are Gusmiati Suid, Huriah Adam, Syoyani Bustamam, and Syahril seen from the perspective of matrilineal and Patrilineal. The matrilineal text cannot only be seen from the genealogical side but it can be viewed from the cultural standpoint. Based on the research result it can be concluded that women participation outside their domestic area is also biased in dance performing arts. Women are not only expected to embellish with their scattering of physical enchanting beauty. They can be the source of ideas and themes, the actress, the creator, the manager, and the event organizer, or the mean of performing arts mobility. These four choreographers were born and grown up in Minangkabau, however, they have actively expanded their career in three different places. Gusmiati Suid's career is in Jakarta, Huriah Adam is in West Sumatra, Syoyani is in Padang, and Syahril is in Padangpanjang. As the choreographers born and grown up in Minangkabau's culture, they definitely feel the dilemmatic sense of women position in Minangkabau society.
\end{abstract}

Keywords: choreographers, Minangkabau, matrilineal, patrilineal 


\section{Pendahuluan}

Kajian mengenai koreografer Minangkabau dibaca dalam teks matrilineal dan patrilineal masih jarang dilakukan. Terutama tentang partisipasinya dalam bentuk tari. Hal ini penting untuk mengetahui sudah berapa banyak koreografer Minangkabau terutama tokoh perempuan dalam budaya dihadirkan dalam bentuk tari. Kehadiran perempuan tidak sekadar pelengkap keindahan ragawi, namun perempuan dapat hadir juga sebagai tokoh yang memberi satu ilham kemandirian. Perbincangan mengenai koreografer dibaca dalam teks matrilineal dan patrilineal memang menarik untuk dikaji. Bagaimana pandangan keempat koreografer Minang ini terhadap perempuan yang kemudian direpresentasikan dalam karya-karya mereka? Untuk menelusuri pandangan keempat koroegrafer dalam karyanya, akan dianalisis melalui karya masing-masing koreografer yang dilihat dari teks matrilineal dan patrilineal.

Perempuan Minangkabau mendapat tempat unik dari sudut pandang budaya. Budaya Minangkabau menganut sistem keturunan matrilineal. Konsep budaya matrilineal ini menawarkan daya tarik bagi posisi perempuan. Konsep inilah yang diduga menjadi lahan subur tumbuhnya sikap androginik pada perempuan Minangkabau (Kuardhani, 2000:101). Disadari atau tidak sedikit banyak mempengaruhi koreografer Minangkabau dalam kehidupannya sebagai seniman maupun dalam kehidupan keluarganya. Koreografer dimaksud adalah Gusmiati Suid, Huriah Adam, Syofyani Bustamam, dan Syahril (koreografer lakilaki). Meskipun Syahril koreografer laki-laki teks tari yang diusungnya hampir selalu mengetengahkan persoalan perempuan dalam sejumlah karyanya. Karya dimaksud seperti Tari Siti Manggopoh, Tari Sirangkak Batuang, Tari Indang Ramolai, dan Tari Itiak Patah.

Gambaran mereka dalam dunia tari dapat dilihat sebagai bagian dari suatu gerakan kaum perempuan dalam berhadapan dengan tradisi yang mengekang perempuan di satu sisi dan modernisasi yang menawarkan emansipasi di sisi lain. Penelitian ini bersifat kualitatif yang sangat bergantung pada kedalaman interpretasi. Untuk mengetahui pandangan koreografer mengenai perempuan yang direpresentasikan dalam karyakarya mereka, teknik atau proses pengumpulan data dilakukan dengan metode triangulasi.

\section{Tari sebagai Teks}

Tari sebagai sebuah teks merupakan sesuatu yang bisa dibaca dan ditafsirkan (Wurystuti, 2012). Artinya sebuah tarian yang terlintas di atas panggung bukan sekadar bentuk susunan gerak dan keterampilan teknik atau virtuosity para penari, tetapi dituntut sebuah pendalaman isi, dan itu semua harus sampai pada sasaran atau "makna komunikatif" kepada masyarakat penonton (Hadi, 2012:9). Tari sebagai teks dengan segala peristiwa di dalamnya merupakan sesuatu yang bisa dibaca dan ditafsirkan dengan bebas seperti halnya membaca sebuah teks (Putra, 1998:20). Penafsiran bebas atas teks harus tetap menggunakan konsep atau sumber acuan yang dapat dipercaya dan bisa memberi tafsir yang tepat. Oleh karena itu, diperlukan interpretasi untuk mengungkap makna tersembunyi di balik makna yang langsung terlihat.

Sebagai sistem simbol, tari juga dapat dianggap sebagai sistem penandaan yang lazim dianalisis melalui pendekatan semiotik. Beberapa aspek yang menjadi bagian dari teks tari seperti gerak, musik iringan, tempat, pola lantai, kostum, rias, dan properti dapat dianalisis ke dalam kategori penanda dan petanda (signifier/signified) yang bersifat arbitrer yang berarti pemaknaannya akan sangat tergatung pada konteks di mana sistem simbol itu disepakati bersama berdasarkan konvensi.

Sebagai sistem tanda, tari terikat pada seperangkat kode yang diananlisis dengan mempertimbangkan konteks yang melatarbelakangi karya-karya tersebut. Tanda seperti yang diketengahkan Charles Sander Pierce mengandung tiga konsep penting tentang tanda, yaitu ikon, indeks, dan simbol. Hubungan antara tanda dan acuannya dapat berupa kemiripan (ikon), kedekatan eksistensi (index), dan hubungan yang terbentuk secara konvensional (simbol) (Kurniawan, 2002:21).

Persoalan tari dapat dianggap sebagai sebuah sistem penandaan (signifying system) di mana pesan- 
pesan tertentu disampaikan. Oleh karena itu, studi untuk mengungkap pesan-pesan ideologis yang dibawanya dapat dianalisis melalui pendekatan semiotik. Tari dengan tubuh dan gerak serta musik dan properti sebagai indeksnya dapat dianggap sebagai penanda (signifier) yang kemudian dapat diuraikan menyimpan suatu petanda (signified) tertentu. Begitupun sebaliknya, tari dengan aspekaspek yang membentuknya dapat dianalisis dengan mempertimbangkan ketiga aspek tanda yang diketengahkan Pierce yakni ikon, indeks, dan simbol.

Dalam bidang tari dikenal tokoh pembaharuan tari Minangkabau: Huriah Adam, Gusmiati Suid, dan Syoyani Bustamam. Belakangan muncul Syahril. Huriah Adam dikenal sebagai perempuan Minangkabau yang beruntung sebab pilihannya untuk berprofesi di bidang seni mendapat dukungan dari ayahnya yang progresif. Sebagaimana diketahui secara tradisional adat Minangkabau yang matrilineal mengekang perempuan di satu sisi dan modernisasi yang menawarkan emansipasi di sisi lain, demikian pula Gusmiati Suid dan Syofyani Bustamam. Mereka dikenal sebagai tokoh atau koreografer yang memperlihatkan konsepsi kreativitas yang khas dalam berhadapan dengan konsepsi fundamental atau pandangan dunia mengenai keterlibatan perempuan dalam dunia seni pertunjukan. Gusmiati Suid, Huriah Adam, dan Syoyani Bustamam merupakan tiga tokoh perempuan Minangkabau yang secara monumental tercatat dalam deretan koreografer Minangkabau yang cukup dikenal di Indonesia. Prestasi mereka ditunjukkan melalui representasi karya-karya mereka baik dalam lingkungan akademik maupun dalam masyarakat kesenian Sumatera Barat. Sementara Syahri adalah sosok koreografer lakilaki yang memiliki kepedulian khusus terhadap persoalan perempuan yang muncul belakangan.

\section{Huriah Adam: Pionir Pembaharu Tari Minangkabau}

Faktor sosial dan kultural mempunyai peran yang cukup berarti dalam penampilan kaum perempuan di dunia tari Minangkabau. Minangkabau memiliki koreografer yang sebenarnya hidup dalam dua dunia, di satu pihak ia adalah bagian dari masyarakat yang masih berpegang pada tradisi, namun di pihak lain, mereka juga masyarakat perkotaan yang terbentuk karena modernisasi pola Barat. Hal ini secara konseptual terlihat kontradiktif. Modernisasi menurut hakikatnya selalu menjauhi hal-hal yang bersifat tradisional yang dianggap menghambat. Dengan kata lain, antara modern dan tradisional secara konseptual bersifat asimetris (Suwarsono, 1991:24).

Kaum adat dan cendekiawan misalnya tidak menunjukkan dukungan secara langsung terhadap dirinya. Sikap demikian tampak dari reaksi-reaksi dan komentar-komentar yang tidak membangun terhadap karya-karya yang diciptakannya. Sikap ini membuat Huriah tetap tegar dengan pendirian dan menentukan pilihannya. Gejala ini sangat dirasakan. Di satu sisi ada semangat untuk membuat perubahan, tetapi di sisi lain harus mempertimbangkan agar karya yang diciptakan dapat diterima di tengah masyarakat. Meskipun ada pembaharuan akan tetapi tidak meninggalkan aspek keunggulan budaya daerah dan nasional. Dalam konteks ini, Sal Murgianto (2005) menyatakan bahwa Huriah Adam adalah orang yang menjunjung tinggi kebebasan sebagai wanita yang baginya tidak hanya sebatas sumarak rumah gadang, tetapi juga terbuka kesempatan bagi wanita untuk memasuki dunia seni pertunjukan.

Oleh karena norma kultural pula, Huriah Adam tidak direstui oleh keluarganya ketika memilih tari untuk dibawa masuk ke dalam bagian kehidupannya. Huriah Adam dikenang sebagai pioner pembaharu tari Minangkabau yang tangkas. Angin segar ditiupkan ke dalam khazanah kehidupan seni pertunjukan tari di Indonesia melalui kiprahnya. Perjalanan terjal melewati garis-garis tradisi yang harus dilalui tidak mampu menghentikan tubuhnya untuk terus menghentak mengikuti irama gerak (Kusmayati, 2009:127).

Mengamati kehadiran Huriah Adam di dunia tari di Minangkabau, sungguh menarik. Wilayah yang dihuni oleh masyarakat yang sebagian besar pemeluk agama Islam ini masih melestarikan sistem kekerabatan matrilineal yang menempatkan perempuan pada kedudukan yang lebih tinggi daripada laki-laki. Namun, mengapa perempuan 
tidak pernah tampil dalam panggung pertunjukan ketika laki-laki di mana-mana di Indonesia merajai dunia seni? Apakah tari dianggap kegiatan yang rendah bagi perempuan? Setelah terjadi kontak dengan dunia luar Minangkabau, kaum perempuan mulai bangkit untuk menunjukkan kiprahnya dalam dunia tari. Para pembaru tari mulai melihat, bahwa di Barat peran perempuan dalam dunia tari sangat menonjol. Bahkan dalam Ballet dahulu penari Ballet pria hanya berperan sebagai pembantu yang lebih banyak membantu gerak-gerak penari balet putri ketika melakukan frase-frase gerak sulit (Narawati, 2003:280). Dalam perkembangan tari modern tokoh-tokoh perempuan Amerika juga mendominasi perkembangan genre baru yang dianggap sebagai tari bangsa Amerika. Dikenal koreografer perempuan legendaris dari Amerika, seperti Isadora Duncan, St. Denis, Martha Graham, Doris Humprey, Helen Tamiri, dan Mary Wigman.

Faktor sosial dan kultural mempunyai peran yang cukup berarti dalam penampilan kaum perempuan di dunia tari Minangkabau. Tidak kalah penting faktor eksternal juga sangat besar pada keberanian Huriah Adam dalam menampilkan tari perempuan yang digarap dengan gerak dinamis, kuat, dan penuh tekanan, yang berpadu dengan kelembutan. Sardono W. Kusumo konon mempunyai peran besar terhadap keberanian Huriah Adam dalam menggunakan vokabuler gerak yang sebenarnya memiliki ciri maskulin, yaitu pencak silat.

Huriah Adam mulai menampilkan karyakaryanya tahun 1960-an. Beberapa karyanya yang terkenal adalah Tari Nelayan, Tari Tani, Tari Sandang Pangan, dan Tari Payung. Tari jenis ini lebih dikenal dengan Minang Melayu. Selain gaya Melayu, Huriah Adam juga memelopori penciptaan tari Minang yang mengambil konsep garapan dari tradisi dan unsur gerak pencak silat yang terdapat di pelosok Minangkabau, seperti Tari Pahlawan yang ditampilkan dalam kegiatan Ganefo di Jakarta. Tarian ini mendapat protes dari kalangan terpelajar di kota-kota, karena gerak-geraknya terlalu keras, dianggap tidak cocok bagi penari perempuan, lebih-lebih menggunakan gerak-gerak pencak silat hingga melahirkan karakter gerak yang sifatnya kejantan-jantanan.
Situasi kultural yang dialami Huriah Adam hingga saat ini masih tetap bertahan di kalangan masyarakat Minangkabau, meskipun benturan dari kaum adat serta cendekiawan itu tidak diungkap secara frontal. Agaknya tidak diragukan lagi diterimanya perempuan dalam seni pertunjukan sangat dikondisikan oleh nilai-nilai budaya yang bersangkutan. Dalam kaitannya dengan Huriah Adam mengenai perempuan, dapat dipahami bahwa perempuan itu disebut Bundo Kanduang merupakan konstruksi sosial yang mengandung bias gender. Pandangan ini memberi pemahaman perempuan adalah hiasan Rumah Gadang. Oleh sistem yang demikian perempuan tidak layak untuk tampil dalam pertunjukan. Sikap ini ditolak oleh Huriah Adam. Aktivitas perempuan dalam seni pertunjukan bukan otonomi laki-laki, karena semua itu merupakan ungkapan diri seorang yang tidak mengenal batas jenis kelamin. Seperti diungkap oleh Yudith Hynne Hanna (1998:3-4) bahwa antara tari, jenis kelamin, dan gender memiliki keterkaitan yang sangat erat dalam konteks sosial dan kultural masyarakatnya. Selain itu, tari sebagai sebuah sistem representasi yang sarat makna dan nilai dapat disebut sebagai sistem simbol. Sebagai sistem simbol, tari merupakan representasi mental dari subjektivfitas seniman. Tari juga dianggap sebagai sistem simbol yang signifikan, artinya ia mengandung arti dan mengundang reaksi yang bermacam-macam. Sistem simbol ini tidak tinggal diam atau bisu, tetapi ia berbicara kepada orang lain (Hadi, 2005:23). Lebih jauh lagi, Hadi menjelaskan bahwa sistem simbol ini lebih menunjuk pada konsep bukan pada artefak atau bendanya. Kehadiran tari secara keseluruhan merupakan kesatuan bulat dan utuh sehingga ia termasuk ke dalam presentasional symbols yang mengacu pada makna tersembunyi. Oleh karena itu, diperlukan interpretasi untuk mengungkap makna tersembunyi di balik makna yang langsung terlihat.

Huriah Adam tidak terlalu lama berkiprah sebagai pioner pembaharu tari Minangkabau. Ia meninggal di usia muda akibat eakibat kecelakaan pesawat terbang. Walau demikian, perannya tesangat menonjol dalam kehidupan tari Minangkabau. Huriah Adam yang memiliki usia 35 tahun (1936- 
1971), mampu mendobrak perkembangan tari Minangkabau menjadi seperti yang sekarang ini. Secara harfiah, arah pembaharuan Huriah Adam itu bisa dipahami sebagai upaya untuk mendefinisikan kembali tari Minangkabau. Memang arah gerak Huriah Adam dalam pembaharuannya benarbenar ingin menampilkan sesuatu yang lain dari tradisi yang telah ada. Dapat diartikan, Huriah Adam akan membuat definisi baru terhadap tari Minangkabau.

Sebelumnya, penampilan tari di Minangkabau lebih didominasi oleh tari-tari Melayu. Dengan tampilnya penari dan koreografer yang gigih ini dalam menggunakan sumber-sumber gerak tari yang digarapnya dari gerak pencak silat Minangkabau, di kawasan ini benar-benar berkembang sebuah genre tari yang khas. Ia mampu memadukan gerak tari yang berakar pada pencak silat sebagai sumber gerak dengan iringan musik yang mendapat pengaruh budaya Eropa seperti akordion dan piano. Perpaduan itu memunculkan ciptaan-ciptaan baru yang berbasis local genius. Kehadiran tari Huriah Adam yang mengarah pada kelahiran suatu genre tari baru, menjadikan karyanya tidak pernah mati. Seni tari yang dimiliki dan digeluti tentu menawarkan berbagai celah untuk direaktualisasikan sehingga nilai yang dikandungnya memiliki kekuatan untuk berbicara kepada komunitas baru yang mendukungnya. Dukungan itu diaplikasikan melalui materi pembelajaran di ISI Padangpanjang, SMKI Padang, dan sekolah-sekolah sederajat.

Jejak Huriah Adam diikuti oleh Gusmiati Suid dalam nuansa yang agak berbeda. Di samping

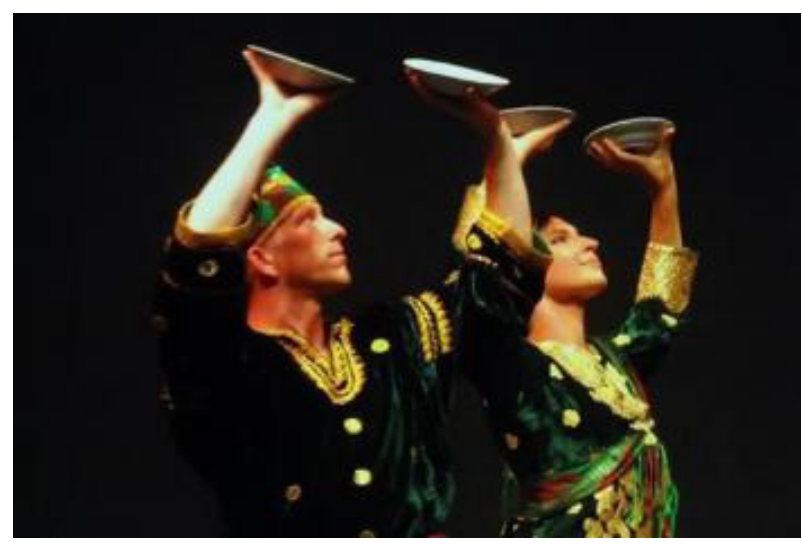

Gambar 1. Tari Piring Huriah Adam dengan iringan akordion. (Foto: Koleksi ISI Padangpanjang, 2014) itu, sebagai koreografer yang lahir dan dibesarkan dalam kultur Minangkabau tentunya kedua koreografer perempuan ini ikut merasakan betapa dilematisnya posisi perempuan dalam masyarakat Minangkabau. Fakta bahwa keduanya lahir dan besar di Minangkabau, tetapi kemudian berkiprah di dua wilayah kultur yang berbeda, Gusmiati di Jakarta dan Huriah Adam di Sumatera Barat, ikut memengaruhi sikap dan pandangan keduanya dalam memaknai perempuan yang kemudian direpresentasikan melalui karya-karya mereka.

\section{Gusmiati Suid: Penari, Koreografer, dan Akademisi}

Gusmiati Suid adalah seorang penari, koreografer, dan akademisi yang seluruh hidupnya diabdikan untuk pendidikan dan kesenian. Reputasinya telah menembus batas-batas nasional. Maka sudah sepantasnya dilakukan upaya pendokumentasian tentang karya, pikiran-pikiran, dan berbagai pendapat serta penilaian masyarakat khususnya para pemerhati seni. Sebagai pimpinan Gumarang Sakti Dance Company, Gusmiati Suid merupakan satu-satunya perempuan Indonesia yang memperoleh penghargaan yang bergengsi bagi kalangan tari, yaitu Baessies Award pada tahun 1991. Sampai akhir hayatnya, Baik Gusmiati tetap setia menekuni jalan yang dipilih, mencipta ,dan menata tari sekaligus menarikannya. Kesuksesan Gusmiati Suid dalam penampilan seni tari sangat dipengaruhi oleh latar belakang pendidikannya. Gusmiati dengan keberaniannya tetap menempatkan diri menjadi salah seorang pengusung tradisi. Hal ini terwujud melalui latihan yang sudah digelutinya sejak masa kanak-kanak. Gusmiati diasuh oleh mamak-nya (paman) untuk belajar silat. Mengapa Gusmiati perlu belajar silat, karena di lingkungan keluarganya tidak ada anak laki-laki. Ia adalah satusatunya cucu dalam lingkungan keluarga ibu dan neneknya. Konon sang paman dalam memberikan pelajaran kepada Gusmiati sangat keras, seperti layaknya memberi pelajaran kepada anak lakilaki (Soedarsono, 2003:393). Selain itu, Gusmiati memperoleh pelajaran mengaji di surau dari salah satu buyutnya, di Koto Panjang (kurang lebih dua kilometer dari Batu Sangkar). Usai mengaji 
biasanya dilanjutkan latihan tari bersama istri mamak-nya (paman). Tarian yang dipelajari adalah tari ke sawah dan Tari Mayopado. Pelajaran silat yang diperoleh di sasaran (tanah luas yang sudah diratakan) serta belajar mengaji di surau (musala) mengawali pergaulannya dengan tradisi pada usia sangat muda. Ketekunan dan keseriusannya dalam mendalami seni tari sudah ditunjukkan dari masa kecil hingga remaja sehingga hari-harinya selalu diisi dengan latihan menari dan pencak silat. Kondisi ini diikuti melalui pendidikan formal yang ditempuhnya. Meningkat dewasa, ia sering tampil sebagai penari alam, dalam acara pesta sekolah. Meskipun ia diperbolehkan belajar silat, tetapi tetap mendapat kekangan dari mamak-nya, (paman). Tidak dipungkiri bila ia dikenal sebagai koreografer yang peka terhadap idiom-idiom gerak-gerak Pencak Silat Minangkabau tidak terkecuali musik yang mengiringi tariannya. Pola gerak tari yang diberikan kepada penari masih dipertimbangkan menurut alur, patut, dan kepantasan menurut raso jo pareso.

Gusmiati Suid adalah salah satu dari sederet nama koreografer perempuan Minangkabau yang dipandang menaruh perhatian besar terhadap peta perkembangan tari Minangkabau. Atas upaya beliau wadah-wadah kesenian mengalami pertumbuhan di tengah masyarakat, meskipun masih langka. Gusmiati banyak belajar tentang tari dari gurunya sang pelopor dan pendobrak tari Minangkabau yang bernama Huriah Adam.

Pada waktu yang hampir bersamaan dikenal pula nama Syofyani Bustamam. Tidak kalah pentingnya muncul sejumlah koreografer muda

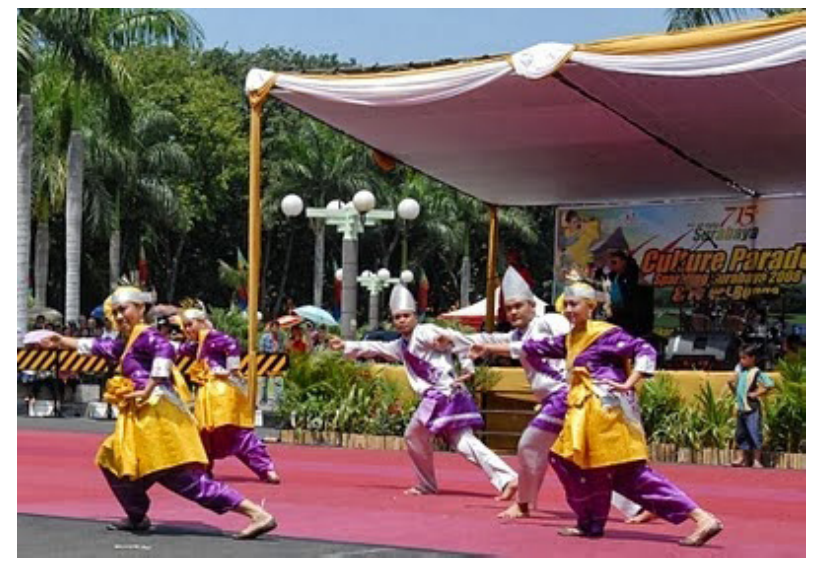

Gambar 2. Tari Rantak karya Gusmiati Suid.

(Foto: Koleksi Surheni, 2009) yang sekarang gencar membangun wadah-wadah dalam bentuk sanggar tari baik yang bersifat amatiran maupun profesional. Para koreografer profesional dan cikal bakal yang mengikutinya berupaya berkarya mendalaminya secara akademik dalam rangka membangun seni pertunjukan profesional Minangkabau. Kiprah mereka dalam dunia tari dapat diamati sebagai bagian dari suatu gerakan kaum perempuan dalam berhadapan dengan tradisi di satu sisi dan modernisasi yang menawarkan emansipasi di sisi lain.

Ciri khas Gusmiati Suid selalu berpijak pada esensi pencak silat yang apabila dibandingkan dengan esensi gaya Martha Graham agak sedikit mirip. Teknik Martha Graham didasari oleh gerakan contract (mengerut) dan release (mengendor), serta fall (jatuh) dan recovery (bangkit). Karyakaryanya mendapat tantangan dari tokoh-tokoh Minangkabau. Tantangan ini memicu semangat untuk terus berkarya. Semangat tersebut terefleksi melalui karya-karyanya yang mengarah pada karakteristik tari modern. Seperti dipaparkan oleh Sumartono (2003:67) bahwa dari sudut pandang fenomenologi karya-karya yang diciptakan lebih bersifat individual didasarkan pada kreativitas masing-masing seniman. Ditegaskan lagi bahwa menciptakan sebuah karya yang menarik lebih penting daripada mencipta karya yang indah.

Karya Gusmiati Suid lebih mengarah pada karya tari yang memiliki karakteristik tari modern. Tari modern, sebagai bentuk tari yang mengekspresikan pandangan kekinian, lebih mementingkan isi dari pada bentuk. Bentuk yang dimaksud dapat diartikan menghilangkan kekangan-kekangan atau aturan-aturan yang mengikat. Kondisi ini terefleksi dalam pengolahan karya tari Gusmiati Suid yang mencoba mengolah tari tradisi ke dalam pola garapan modern sehingga roh keminangkabauannya tetap dapat dirasakan.

Secara tradisional, konsep tari Minangkabau yang bersifat matrilineal mengakibatkan peran mamak (paman) sangat berperan mengawasi anggota keluarga, sehingga tidak memberi peluang bagi kemenakan perempuan untuk menari. Tidak heran jika Wisran Hadi (2006:2) kemudian menyebut tari Minangkabau sebagai dunia hiburan tanpa perempuan karena panggung hiburan 
sepenuhnya adalah milik laki-laki. Kemunculan perempuan dalam dunia tari baru dijumpai pada awal abad kedua puluh (Murgianto, 2007).

Gusmiati Suid tidak hanya belajar silat dan mengaji di surau, tetapi tanpa sepengetahuan pamannya ia turut kegiatan latihan belajar menari. Kegiatan yang terakhir ini mendapat tantangan dari pamannya. Ada anggapan dari keluarganya bahwa menari adalah perbuatan maksiat, jika kesenangan belajar menari itu dilanjutkan pamannya akan membunuhnya (Murgianto, 1991:233-315). Ancaman tersebut tidak mengurangi semangat untuk tetap belajar menari. Bahkan dalam waktu singkat Gusmiati dapat menguasai sejumlah tari-tarian yang diajarkan oleh seorang guru tari bernama Syofyan Naan. Penguasaan tari yang dimilikinya membuka peluang tampil dalam perayaan-perayaan di sekolahnya. Tidak heran ketika Gusmiati duduk di bangku SMP, selain dianggap jagoan silat juga terampil dalam menari. Bakat yang dimiliki Gusmiati tidak hanya sampai di situ, setelah menamatkan SMP pada tahun 1957 di Padangpanjang, melanjutkan ke sekolah guru (SPG). Di sekolah inilah ia bertemu dengan Huriah Adam yang piawai dalam menari. Pertemuan inilah yang memotivasi semangat Gusmiati untuk menjadi seorang penari dan koreografer seperti halnya Huriah Adam yang dalam peta perkembangan tari Minang dialah yang berupaya memantapkannya. Dengan demikian, walaupun Gusmiati adalah murid Huriah Adam, dalam kiprahnya sebagai seorang koreografer ia menghasilkan karya-karya yang tidak persis sama dengan karya gurunya. Kreativitas Gusmiati terus berkembang, bahkan menjadi guru di berbagai sekolah umum dan memenuhi berbagai permintaan untuk menampilkan karyakaryanya di Sumatera Barat. Setelah menyelesaikan sekolah guru tahun 1960, Gusmiati melanjutkan ke Fakultas Ilmu Keguruan dan Kependidikan, dengan mengambil Jurusan Bahasa Indonesia. Meskipun bidang yang ditekuninya tidak relevan dengan tari, ia tetap antusias membidangi tari, bahkan memperdalam pengetahuan tari melalui pendidikan yang membuka jurusan tari (Akademi Seni Karawitan Indonesia) Padangpanjang tahun 1972 dan menyelesaikan kesarjanaan mudanya pada tahun 1975 .
Dengan ketekunan hati, Gusmiati makin kokoh kedudukannya dalam khazanah tari Minangkabau. Bahkan karya-karyanya sampai sekarang masih tetap mewarnai peta perkembangan tari Minangkabau, seperti Tari Payung, Tari LayangLayang, Tari Nelayan, Tari Cewang di Langik, Tari Panen, dan Tari ke Sawah. Oleh karena kepiawaiannya yang sangat menonjol, ia diangkat sebagai tenaga pengajar tetap di ASKI Padangpanjang. Tari Rantak, karya yang dilahirkan Gusmiati tahun 1978, hingga kini masih tetap menjadi reportoar tari Minangkabau. Tari tersebut juga terpilih untuk ditampilkan dalam Festival Tari Rakyat Nasional di Jakarta. Selain itu, tari Rantak dianggap sebagai karya master piece yang dapat mewakili etnis Minangkabau di forum nasional dan internasional. Sebelum muncul Tari Rantak, sulit membedakan antara tari Minang dengan tari Melayu. Bagi masyarakat pendukung budaya Minangkabau mereka telah menemukan identitas tari Minangkabau yang sesuai dengan dinamika budayanya.

Kesuksesan Gusmiati dalam menyebarluaskan Tari Rantak tidak hanya terpaku pada geraknya yang tajam dan lincah, tetapi instrumen perkusi yang dibunyikan juga memberi kepuasan tersendiri bagi pendengarnya. Hal ini dijelaskan oleh Farida Feisol, salah satu faktor yang menyebabkan Tari Rantak diterima oleh masyarakat luas adalah musik yang mengiringinya. "Musik itu mampu memberikan semacam rangsangan, melalui pendengaran memikat, perhatian kita”. Ia juga berhasil mempertahankan semangat tradisi untuk basis karya kesenian modernnya, seperti yang dicita-citakannya.

Tahun 1979 merupakan awal perjalanan Gusmiati mengikuti rombongan misi kesenian pemerintah yang ditugasi Nyonya Neli Adam Malik, istri Wakil Presiden Adam Malik untuk melakukan lawatan ke luar negeri. Selang beberapa tahun kemudian, ia diundang dalam Asian Festival of Theater and Martial Arts di Calcuta, Hongkong, Amerika, Singapore, Toronto, Montreal, Vancouvar, dan Jepang. Sejak peristiwa inilah Gusmiati Suid mulai yakin bahwa dengan tari ia bisa tampil sebagai duta bangsa dan negara.

Meskipun karyanya memiliki karakteristik tari modern, rasa keminangkabauannya kental dan pekat dalam membuat karya baik garapan yang 
kuat dengan tradisinya maupun garapan yang kontemporer selalu memberi keleluasaan yang besar untuk menghimpun, memenggal, meramu unsur-unsur atau aspek-aspek dari berbagai sumber untuk sebuah garapan baru. Ia selalu merasa tidak puas dan menganggap karyanya memang menjadi sumber inspirasi yang terus mengalir sehingga selalu ada kemungkinan dan peluang untuk mengeksplorasi kembali. Hal ini sejalan dengan pendapat Sedyawati (2008:152), bahwa seni tradisi perlu dilestarikan. Pelestarian suatu kesenian bukan berarti membekukan di dalam bentuk-bentuknya yang sudah dikenal saja. Dalam kenyataannya kesenian senantiasa berada dalam dalam proses berkembang, menyusut, berubah, atau bertransformasi.

Gusmiati telah tiada, kepopulerannya sebagai koreografer dan seniman dilanjutkan oleh anak sulungnya, Boy G. Sakti. Selaku anak sulung ia telah berhasil meneruskan jejak ibunya sebagai koreografer berprestasi, baik di tingkat nasional maupun internasional. Karyanya saat ini dianggap sebagai salah satu barometer perkembangan tari Minangkabau baik secara kualitatif maupun kuantitatif. Proses kerja dan eksplorasi yang telah dilakukannya banyak menghasilkan karya-karya tari yang cukup spektakuler.

Dua koreografer Minang, anak dan ibu memiliki kesamaan namun tetap memiliki ciri khas yang berbeda sebagai koreografer tari Minang. Sang ibu, Gusmiati Suid adalah murid Huriah Adam, koreografer dan pelopor bagi tumbuh dan berkembangnya tari Minangkabau di Sumatera Barat, tepatnya di Padangpanjang. Ia telah meneruskan berbagai upaya gurunya menggali khazanah tari tradisi Minang yang tidak monolitik (karena banyak terdapat di berbagai pelosok nagari). Tradisi Minangkabau dengan maknanya untuk mengolah dan menata kembali menjadi suatu karya tari baru yang tidak kehilangan esensinya (Rustianti, 2009:106). Tari Rantak karya Gusmiati Suid diakui sebagai tari kreasi yang mentradisi. Meskipun sampai saat ini Tari Rantak lebih dikenal sebagai tari kreasi, jika ditelusuri lebih jauh Tari Rantak dapat dikategorikan dalam tari tradisi karena sudah lama berkembang dan mendapat pengakuan dari masyarakat akademis maupun masyarakat seni Sumatera Barat. Selain itu, tari ini mewakili tarian etnik Minangkabau di forum nasional maupun internasional.

Gusmiati Suid dikenal sebagai koreografer konservatif yang amat setia dalam pelestarian dan pengembangan nilai-nilai tradisi budaya Minangkabau yang ada sebelumnya. Karya-karya tarinya pada periode awal, yaitu tahun 1960-an sampai dengan tahun 1975 tidak jauh berbeda dengan karya Huriah Adam dan Syofyani bahkan terlihat bahwa karya Gusmiati pada masa itu hampir segaya dengan tari Huriah Adam dan Syofyani Bustamam. Dalam hal ini Gusmiati lebih cenderung melahirkan gaya tari yang bertema tari pantomim dan permainan muda mudi. Gaya tari semacam ini terlihat dalam karya berupa Tari Cewang di Langik, Tari Nelayan, dan Tari Payung (Erlinda, 2011:274).

Tari Rantak sebagai karya masterpiece Gusmiati sering dipergelarkan dan mewakili etnis Minangkabau di forum nasional dan internasional. Keberhasilannya mempertahankan semangat tradisi untuk basis karya kesenian modern, seperti yang dicita-citakannya. Tidak heran jika Tari Rantak sudah menyebar ke mana-mana. Selain itu, Tari Rantak disosialisasikan di lembaga-lembaga kesenian Minangkabau di Jakarta, Bandung, Yogyakarta, Medan, Surakarta, dan Sumatera Barat. Sampai saat ini Tari Rantak dijadikan materi ajar di lembaga pendidikan menengah dan perguruan tinggi seni. Rantak tidak hanya dipelajari di sanggarsanggar tari seperti Gonjong Limo, Sangrina Bunda, Anjungan Sumatera Barat di Taman Mini Indonesia Indah, Ganto Sori (Yogakarta), Sarangkuah Dayuang (Surakarta), dan beberapa kelompok seni masyarakat perantau Minangkabau di seluruh Indonesia. Tidak kalah pentingnya Tari Rantak juga menembus lembaga pendidikan formal seperti SMKI Padang, SMKI Bandung, Institut Seni Indonesia (ISI) Padangpanjang, FKIP Universitas Riau, ISI Yogyakarrta, ISI Surakarta, dan ISI Denpasar. Berbagai forum nasional dan internasional, termasuk forum-forum promosi wisata Indonesia berkali-kali membawa Tari Rantak dalam misinya (Rustianti, 2009: 112).

Sebagai perempuan Minangkabau, Gusmiati tetap teguh menempatkan dirinya menjadi salah seorang pengusung tradisi. Hal ini dilakukan 
melalui penelusuran akar tradisi yang sudah dikenalnya puluhan tahun lalu sejak pada masa kanak-kanaknya. Kecintaan dan kekuatan pada tradisi diwujudkannya ke dalam bermacammacam koreografi yang tetap bertahan pada akar penunjangnya. Seiring dengan koreografi yang dibuatnya, ia pun menapaki sendiri lantai tari menjadi pelakunya (Kusmayati, 2009:127). Kekuatan Gusmiati lebih cenderung pada teks matrilineal, walaupun karakteristik tarinya mengarah pada karakteristik tari modern tidak membuatnya silau dengan makhluk yang bernama modern itu. Ia sadar bahwa modernisme adalah pada cara berpikir, bukan suatu ide dan bukan materi. Inilah ciri khas yang membentuk karya Gusmiati Suid lebih mendominasi teks matrilineal dalam sejumlah karyanya seperti Tari Rantak, Ttari Panen, Tari Cewang di Langik, Tari Kasawah, dan Tari Gandang.

Pada tahun 1958 Gusmiati mendapat asuhan dan dorongan dari Huriah Adam. Ia diperkenalkan secara mendalam tentang tari yang berdasarkan pencak silat tradisi Minangkabau. Seni tradisi tersebut dijadikan sumber inspirasi dalam karyakaryanya. Dapat dikatakan ciri khas garapan Gusmiati Suid berorientasi pada gerakan-gerakan yang kuat, berkualitas tinggi, dan mengarah pada pencapaian kualitas estetik. Karakater kuat, dinamis, dan cepat terkesan dalam bentuk karyakaryanya menyebabkan adanya reaksi keras dari tokoh masyarakat Minangkabau. Reaksi itu tidak memberi pengaruh, ia terus berkarya. Karyakaryanya dengan segar merefleksikan konflik sosial yang terjadi dalam masyarakat. Itulah keunggulan Gusmiati Suid, ia peka terhadap lingkungan dan cepat tanggap terhadap fenomena sosial. Imajinasi dan ketajamannya, ia lahirkan lewat karyanya. Hadi (2001:17) menjelaskan kesenian yang tumbuh atau lahir di dalam kondisi sosial tertentu, kondisi itu sebagai kekuatan proses kesenian. Seluruh imajinasi dan perasaan manusia tak dapat dipisahkan dari pengaruh sosial dan akan mempengaruhi pengalaman kreatif .

Melalui pergelaran, tidak sedikit perempuan yang telah teruji seperti juga yang menjalani kegiatan di sebalik tirainya. Kegiatan yang tidak tampak di panggung ini tidak hanya sering menyita waktu dan pikiran, tetapi juga tenaga yang dibutuhkan. Akan tetapi, para perempuan, siap dan tekun melaksanakannya. Tidak disadari bahwa dari balik panggung aspek-aspek seni tradisi ditransmisikan (Kusmayati, 2009:128). Kondisi yang sama dijalani juga oleh Gusmiati Suid. Ia mampu menjadi agen perubahan dan persebaran wilayah seni pertunjukan (tari) dalam pengertian yang lebih luas, ia bertekad untuk merombak kebiasaan-kebiasaan yang kaku dan berupaya memprakarsai pembaharuan-pembaharuan sesuai dengan perkembangan zaman. Di posisi seperti ini para koreografer mengakui konsep pembaharuan yang telah dicetuskan oleh Huriah Adam. Mereka selalu mengenang karya tari yang digagas Huriah Adam dan menjadikannya sebagai sumber garapan.

Konsep dasar Gusmiati dalam berkarya selalu konsisten dengan nilai-nilai yang bertolak dari ungkapan adat Minangkabau, misalnya "alam takambang jadikan guru” (alam terkembang jadi guru). Ungkapan bersahaja ini kiranya bermuatan pesan bergurulah kepada alam; pelajarilah alam itu untuk sampai pada hakikat makna yang tersirat, yang tidak lain adalah kebenaran. Kebenaran itu adalah Sang Pencipta Alam Semesta itu sendiri. Berguru dan meraih kebenaran itu seharusnya menggunakan raso (rasa) dan pareso (akal pikiran). Rasa dan akal pikiran menjadi seiring, setelah kebenaran berdasarkan akal pikiran itu diuji dengan rasa. Sebaliknya, kebenaran sebagai pancaran rasa diuji dengan akal pikiran. Lalu keduanya masih akan diuji lagi dalam alur (alua) yang bermuatan sifat dan hukum alam yang mungkin patut (patuik). Kepatutan itu sendiri bermuatan etika, kesusilaan, dan hati nurani. "Lamak dek awak katuju dek urang" ia menganut pandangan bahwa setiap insan mempunyai hak untuk mewujudkan pengalaman emosionalnya melalui seni pertunjukan. Semuanya itu merupakan konfigurasi budaya yang masih dipandu oleh keyakinan agama, yang berfungsi sebagai acuan bagi kehidupan sosial yang sedemikan luasnya (Sastra, 2012:1). Bertolak dari pemikiran ini, muncul pertanyaan adakah dan bagaimanakah sentuhan konfigurasi itu dalam karya Gusmiati Suid, yang juga sebagai tempat belajar dan becermin? Olah geraknya terasa bernuansa gerak dinamis pencak silat. Pola gerak itu merupakan 
simbol akal pikiran yang menyiratkan makna keterbukaan dan kewaspadaan sebagai simbol acuan dalam merespons tantangan, seiring dengan perubahan lingkungan alam, lingkungan sosial, dan budaya. Di sisi lain, musik yang mengiringinya dipahami, misalnya dalam irama yang tegas, kuat, dan bentuk tata bunyi nan indah.

Rupa-rupanya kedua nuansa tadi harus ada dan berjalan seiring dalam alur dan patut menyiramkan sesuatu yang harmoni, sebagai rasa, nilai, sekaligus acuan jati diri kreativitas seorang koereografer. Seseorang tidak pantas jadi koreografer tanpa kreativitas, kualitas karya, dan lain-lainnya. Ia akan tergilas oleh sistem kesenian tradisi itu sendiri. Sistem itu menyebabkan kesenian tradisional melahirkan karya-karya baru. Jadi, tidaklah tepat kalau kesenian tradisional itu dituding bersifat statis, dangkal, kasar, menolak perubahan, tidak kreatif, dan lain-lain. Bertolak dari nuansa inilah Gusmiati Suid mencoba melakukan perubahan-perubahan, tanggap terhadap gejolakgejolak sosial yang kemudian diungkapkan melalui karya-karyanya. Jika disimak perjalanan kariernya, ia mencapai kesuksesan secara berkesinabungan. Ia menunjukkan kebolehannya melalui karya tari dengan segala kebaruan. Kesuksesan itu diraihnya karena ia jeli, peka, dan peduli terhadap gejala aktual sehingga karyanya mewakili selera pada zamannya. Selain daya kreatitiviasnya yang intensif, keberhasilannya ditunjang oleh penaripenari yang matang kemampuan geraknya. Ia lebih memfokuskan pada bentuk gerak tari dalam karyanya. Orientasinya adalah mengangkat gerak tradisi ke dalam keinginan membangun khazanah gerak tari Minangkabau. Kepeduliannya terhadap pencak silat yang dikemas menjadi sumber garapan dan diberikan kepada penari-penari perempuan. Hal ini mengundang perhatian masyarakat bahkan mendapat kecaman dari para tokoh adat dan agama. Di kalangan konservatif gerak pencak silat adalah gerak laki-laki karena bersumber dari gerak bela diri tradisional maka karakter geraknya kelihatan dinamis, keras, tegas, dan boleh dikatakan jauh dari imajinasi kegemulaian feminis (Astuti, 2004:152). Dalam konteks inilah karya-karya garapan Gusmiati Suid pada awalnya sangat sulit diterima di kalangan masyarakat Minangkabau.
Kegigihan yang dimiliki Gusmiati Suid dalam menghasilkan karya-karyanya cukup produktif melalui elemen-elemen yang dijiwainya. Rasa keminangkabauannya kental dan pekat walau menyerap konsep modern. Gusmiati dalam membuat karya baik garapan yang kuat dengan tradisinya maupun garapan yang kontemporer, selalu memberikan keleluasaan yang besar untuk meramu unsur-unsur atau aspek-aspek dari berbagai vokabuler sebuah karya baru. Banyak karya tari yang telah dihasilkannya, seperi Tari Rantak, Tari Alang Babega, Tari Panen, dan Tari Gandang. Selain itu, juga ada karya kontemporernya, seperti Pertemuan Dua Warna, Bulan Maraok, Asa di Ujung Tanduk, Api dalam Sekam, dan Menggantang Asap.

Karya Gusmiati banyak memanfaatkan konsep modern, dalam hal teknik gerak yang cepat, ringan, melayang, dan gerak sentak, menjadi ciri khas karya-karyanya yang sangat dipengaruhi aliran Silat Kumango yang diwariskan dari mamaknya. Itulah ciri khas Gusmiati yang tangkas dan gesit. Meskipun perubahan sosial turut serta mengiringinya, ia tetap kukuh tidak kehilangan jati dirinya dalam setiap karyanya.

\section{Syofyani Bustaman: Konsep dan Kreatifitasnya}

Sebagai koreografer perempuan Minangkabau, Syofyani Bustamam mempunyai kiprah tersendiri dalam dunia seni pertunjukan. Olah gerak yang diungkapkan memiliki kesamaan dengan karya $\mathrm{Hu}$ riah Adam. Kesamaan itu terlihat dalam ideologi berkarya. Mereka sama-sama berangkat dari unsur tradisi sebagai bahan garapnya, dan memiliki keterampilan dasar sebagai pemain musik, yaitu samasama pemain musik nontradisional. Huriah Adam terampil sebagai pemain biola, sedangkan Syofyani terampil memainkan akordion. Kesamaan ini juga memiliki kemiripan dalam karya tari. Karya mereka sama-sama cenderung mempergunakan musik diatonis, meskipun kadang-kadang tidak mempergunakan biola, piano, dan gitar, tetapi mempergunakan alat musik tradisional Minangkabau yang telah diinovasi (Erlinda, 2011:272).

Meskipun Syofyani dan Huriah Adam memiliki kemiripan dalam kemampuan dasar sebagai koreografer Minangkabau, mereka 
memiliki perbedaan lingkungan sosial yang turut memengaruhi kreativitasnya. Huriah Adam adalah perempuan Minangkabau yang berdomisili di Padangpanjang atau yang lebih dikenal kota Serambi Mekah, sedangkan Syofyani Bustamam dari Bukitinggi, yang disebut juga kota wisata. Huriah Adam berkreativitas di ASKI Padangpanjang (sekarang ISI Padangpanjang), sedangkan Syofyani Bustamam berkreativitas di lingkungan IKIP Padang (sekarang Universitas Negeri Padang).

Persamaan dan perbedaan kedua koreografer tersebut dapat dilihat dalam penggunaan musik diatonis sebagai musik tariannya, dan inovasi musik talempong dari nondiatonis dengan sistem permainan interluc menjadi musik diatonis dengan sistem permainan melodi dan akor. Selain itu, mereka cenderung mempertunjukkan gerak tari yang lembut, meskipun ada perbedaan karakter gerak tari masing-masing mereka. Kelembutan dan keharmonisan antara gerak dan musik menjadikan tarian Syofyani terkesan ringan, santai, dan estetis sehingga remaja-remaja putri senang menarikan ciptaannya yang tercermin dalam Tari Payung. Meskipun tarinya berkesan tarian erotik berpasangan, pola gerak dan komposisi yang ditampilkan masih tetap dalam batasan-batasan yang wajar.

Syofyani dalam pengembangan kariernya tidak mendapat kecaman dari lingkungan masyarakat sebagaimana yang dialami oleh Gusmiati Suid dan Huriah Adam. Hal ini disebabkan Syofyani tidak melakukan pendobrakan terhadap konvensikonvensi kultural yang sudah mapan di tengah masyarakat Minangkabau. Ia lebih banyak mengetengahkan gerakan-gerakan lembut, tetapi

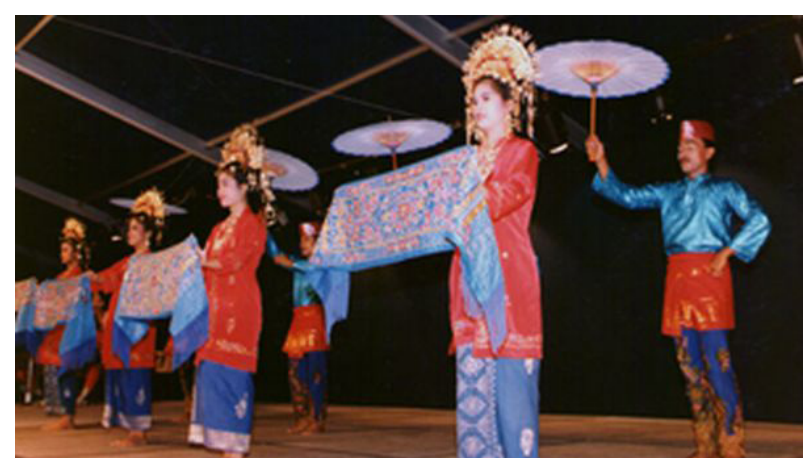

Gambar 3. Tari Payung Syofyani.

(Foto: Koleksi fandilarama.blogspot.com, 2014) tidak meninggalkan kesan estetis dalam setiap garapan tarinya. Tari yang dimaksud antara lain Tari Piring, Payung, dan Tari Saputangan. Syofyani berhasil menampilkan karya-karya untuk konsumen perkotaan. Kondisi ini tidak terlepas dari bakat yang diwarisi dari pihak keluarga, yaitu keluarga seniman perkotaan. Pengaruh lingkungan keluarga seniman tersebut sangat memberi dukungan dalam pengembangan kariernya. Pengembangan-pengembangan yang dilakukannya mendapat perhatian dan sambutan baik dari pemerintah daerah maupun masyarakat Minangkabau sehingga ia banyak mendapat tawaran untuk mempertunjukkan karyanya baik di dalam maupun luar negeri. Pengalaman dan kiprahnya dalam dunia tari Minangkabau memberikan banyak arti terhadap pengembangan tari Minangkabau. Hal ini dapat dilacak karena pamannya Saugi Bustami juga seorang seniman yang berjasa dalam pengembangan kesenian Minangkabau, seperti diketengahkan Sedyawati (1999:15):

"Saugi Bustami dan Huriah Adam adalah tokoh-tokoh tari Minangkabau yang mengembangkan karyanya di luar Minangkabau. Tokoh-tokoh tari yang mengembangkan karya-karya tarinya di kota-kota tidak bertolak dari satu tradisi 'supra desa' tertentu, tetapi dalam membuat dan mengembangkan tari Minangkabau tersebut para penata tari mencari sumber ke nagari-nagari tertentu, sesuai dengan selera dan peluang masing-masing."

\section{Syahril: Koreografer Laki-laki Mengangkat Isu Perempuan}

Syahril adalah salah seorang koreografer laki-laki Minangkabau yang muncul dengan kekhasannya. Kekhasan itu ditunjukkan melalui kepedulian yang lebih terhadap berbagai isu perempuan. Hal ini terlihat dari berbagai karyanya yang bicara tentang perempuan. Perempuan yang berkarakter dan berpredikat popular sering menjadi pilihan untuk sumber garapan penyajiannya melalui penelusuran akar tradisi yang sudah dikenalnya semenjak remaja. Karya-karyanya 
yang bersumber pada tema cerita, gerak, dan musik tradisi menghantarkannya dan diterima dalam berbagai event seni bertaraf nasional dan internasional. Karya yang dimaksud antara lain Indang Ramolai, Indang Siti Manggopoh, Nagari Itiak Patah, Sirangkak Batuang, dan Kurenah. Sebagai koreografer laki-laki Minangkabau, ia memiliki karakter kuat yang berperilaku tangguh dan mampu menggeser persepsi masyarakat maternalisitik terhadap perempuan. Ketangguhan, kekuatan, dan kearifan yang diungkapkan menepis tempat perempuan dengan lawan jenisnya. Istilah perempuan yang dikenal Bundo Kanduang secara sekilas dapat dipahami bahwa perempuan Minang hanya berhak berperan di sektor domestik. Akibatnya, setiap aktivitas dan peran perempuan di publik selalu mendapat sorotan satu tempat yang paling privat, tidak berhadapan dengan masyarakat umum. Konsep itu tidak diterima begitu saja, Syahril berpandangan bahwa ia tidak dapat menerima kondisi seperti itu. Perempuan harus tetap tegar. Ketegaran itu ditransformasikan melalui kreativitasnya di atas panggung.

Melalui pergelaran, tidak sedikit perempuan yang telah teruji seperti juga yang menjalani kegiatan di sebalik tirainya. Kegiatan yang tidak tampak di panggung ini tidak hanya sering menyita waktu dan pikiran, tetapi juga tenaga yang dibutuhkan. Akan tetapi, para perempuan siap dan tekun melaksanakannya. Tidak disadari bahwa dari balik panggung inilah aspek-aspek seni tradisi ditransmisikan (Kusmayati, 2009:128). Demikian pula Syahril mengaku bahwa karya tarinya terinspirasi dari pengalamannya sebagai seorang laki-laki sekaligus individu yang melingkupinya. Siklus hidup yang dijalani menjadikan ideologi dalam setiap karya tarinya, tetapi seiring dengan koreografi yang dibuatnya ia pun menjalani sendiri Ide dasar atau rangsang awal yang mengilhami terwujudnya gerak Tari Indang Ramolai dan Indang Siti Manggopoh diperoleh berdasarkan gerak Tari Indang Pariaman, Indang Tuo Maninjau, dan Indang Tagak Padang Magek. Sementara itu, Tari Itiak Patah bersumber pada alam takambang jadi guru (alam terkembang jadi guru). Istilah Itiak Patah, bermuatan pesan yang dalam, sesuai tema yang diusung tari itu sendiri.
Itiak Patah mengangkat kondisi perempuan dalam kesenjangan dunia baik ditinjau dari segi tradisi sosiologi hingga proses pencarian jati diri perempuan dalam individu yang berada dalam keterkaitannya dengan alam, agama, dan budaya. Kesenjangan atau ketimpangan memacu semangat untuk tetap tegar.

Sebagai koreografer laki-laki, kepedulian yang lebih terhadap berbagai isu perempuan, menarik untuk diteliti. Apakah peran perempuan sebagaimana persepsi budaya matrilineal tetap muncul ataukah dibiaskan oleh sudut pandang patriarki. Hal ini tercermin dalam karya Tari Indang Siti Manggopoh. Ia mencoba mengetengahkan figur perempuan sebagai pemimpin perjuangan yang mampu menjadi inspirasi bagi pengikutnya. Ia berpendapat bahwa sifat keperkasaan tidak hanya milik laki-laki. Perempuan dengan keperkasaan yang dimilikinya ternyata mampu menjadi pemimpin dan pahlawan yang disegani kawan ataupun lawan. Selain itu Syahril, juga menyikapi bahwa perempuan Minangkabau tidak hanya sebatas semarak rumah gadang, tetapi juga terbuka kesempatan bagi perempuan untuk memasuki dunia seni pertunjukan.

Ketiga karya tari yang ditampilkan tetap berorientasi pada pencak silat, meskipun dua karya yang diketengahkan bernuansa islami. Syahril mampu memadukan idiom-idiomnya yang tidak hanya berpatokan pada ideologi teks matrilineal tapi teks patrilineal. Ideologi teks matrilineal

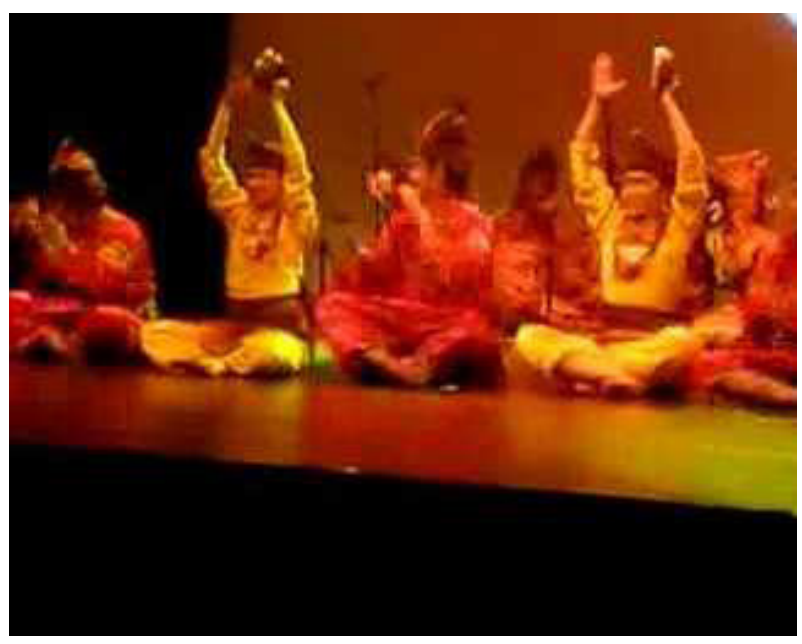

Gambar 4. Tari Indang Ramolai, teknik gerak yang dinamis mewarnai karyanya meskipun tarian ini bernuansa agamis. (Foto: Koleksi Pertunjukan TongTong Festival Belanda, 2009) 
dapat diamati melalui gerakan yang dimunculkan berpatokan pada pencak silat meskipun tarian ini bernuansa Islam. Sementara vokal atau syair-syair yang diketengahkan memberi kesan berulang, bersahutan, dan berkesinambungan antara setiap lirik yang dinyanyikannya, sehingga memunculkan suasana damai dan tenang. Hal ini sejalan dengan pendapat Sarjiwo (2011:181) bahwa iringan tari merupakan salah satu faktor penting yang mampu membangun suasana, dapat menghasilkan penguatan terhadap garapan tari, serta mampu membentuk atmosfer yang mampu menyatukan seluruh gagasan.

Tampilan musik vokal diperkaya dengan tabuhan gendang yang bersumber dari pukulan rebana dengan karakter suara rendah atau yang ajeg teratur seirama detak jantung, yang kian lama kian berubah kecepatan dan intensitasnya sesuai dengan kebutuhan karakter gerak dan suasana yang ingin dicapai. Hal ini dapat disaksikan dalam Tari Indang Ramolai dan Indang Siti Manggopoh yang berangkat dari tradisi Indang Pariaman, Indang Maninjau, dan Indang Tagak. Masing-masing karya tersebut menunjang dan memperkuat penampilan keindahan di dalam perwujudannya. Tangan yang menabuh rebana secara ritmis dan cepat dalam Tari Indang Ramolai tidak memiliki kemungkinan untuk bergerak lebih jauh. Akan tetapi, keterbatasan gerak yang dipertunjukkan tidak mengurangi intensitas yang ingin dicapai. Irama musik yang semakin membahana diiringi dengan vokal serta gerak tari yang dinamis mampu menjadi mitra, bahkan memperkuat gerak yang

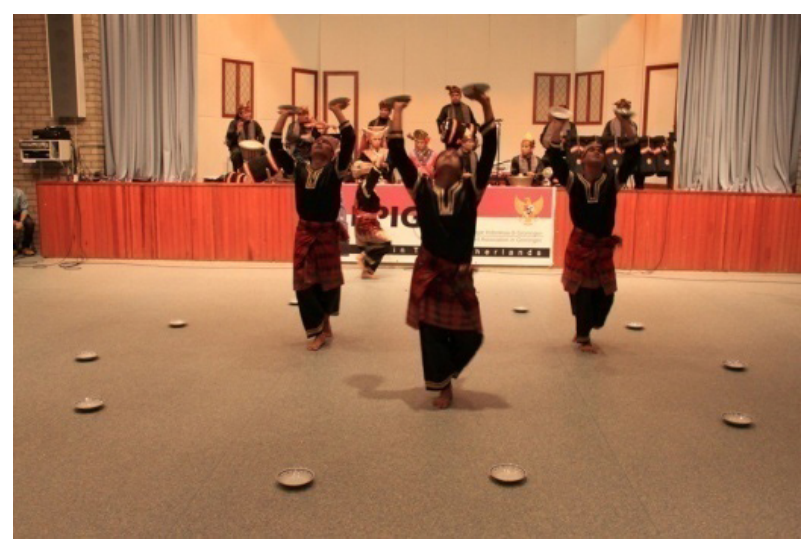

Gambar 5. Pertunjukan Tari Garak Nagari Itiak Patah dalam acara Festival Tong-Tong di Belanda (Foto: Koleksi Syahril, 2009) ditampilkan. Bagaimana kontrasnya gerak tari yang begitu dinamis dan heroik terpadu dengan suara merdu? Karya Syahril memberikan pemahaman tentang bagaimana muatan rasa dan akal pikiran melahirkan keseimbangan, disemat dalam tariannya yang sekaligus berfungsi sebagai acuan bagi kehidupan.

Pola hubungan tari dengan irama musik semacam ini muncul pula dalam tari Itiak Patah. Itiak Patah merupakan gagasan yang mencoba melihat situasi manusia dalam dua sisi yang bersebrangan seperti halnya kehidupan dan kematian. Termasuk manusia merasa ada kesenjangan-kesenjangan di antara salah satunya. Situasi sosial di mana manusia merasa ada satu sisi yang dapat sementara satu sisi hilang. Hidup harus terus digulirkan, meskipun terseok-seok jatuh bagaikan Itiak Patah (itik yang kakinya patah). Itiak Patah berangkat dari filosofi silat Minangkabau, yaitu garak jo garik sebagai dasar metode penciptaanya. Garak merupakan kekuatan intuitif dalam bergerak, sementara Garik kekuatan mekanis yang dibangun berdasarkan geraknya. Perpaduan garak dengan garik melahirkan berbagai kepekaan penari di atas panggung. Termasuk kepekaan terhadap musik. Pesan yang disampaikan sebagai simbol ketidakberdayaan terbangun oleh sifat "kompetitif" karyanya terinspirasi dari genre musik si Jobang dari Payakumbuh Kabupaten Lima Puluh Kota. Namun, pola gerak tetap berorientasi pada silek Kumango. Hal ini terlihat pada gerak kaki ditekuk dalam posisi rendah. Teknik gerak yang dilakukan selalu dalam hitungan ganjil, misalnya tiga atau lima hitungan. Motif gerak tersebut sangat bervariasi misalnya antara motif gerak pertama, motif gerak kedua, dan motif gerak ketiga tidak pernah sama meskipun terjadi pengulangan gerak. Ia mampu mengembangkan dalam bentuk lain, meski berangkat dari silek kumango, ekspresi yang ditampilkan lebih mengutamakan isi daripada bentuk. Tidak heran jika karya Syahril sangat dipengaruhi oleh karakteristik silat yang bersifat dinamis, atraktif, dan bertumpu pada kekuatan fisik.

Penggunaan piring sebagai properti dalam tari Itiak Patah berbeda dengan tari piring lain, misalnya Tari Piring Huriah Adam, dan Tari Piring Syofyani. Misal pada motif gerak pantak 
kararanggo, ada tekanan-tekanan tertentu serta pemutaran pada pergelangan tangan dari berbagai kontras yang dihadirkan, dibalik ketenangan yang menumbuhkan kesan asimetris. Baik kontras maupun ketenangan hadir melalui gerak, suara serta rupa yang muncul kepermukaan. Volume gerak yang lebar dengan jangkauan yang luas tampil kebalikan dengan volume yang sempit. Akan tetapi level yang dihadirkan hampir selalu menggunakan medium dan tinggi. Orientasi garapan geraknya bertumpu pada idiom-idiom gerak Minangkabau yang atraktif dan dinamis. Konsepsinya merupakan kombinasi dari pandangan tradisi dan Islam yang tercermin dalam syair-syair yang dikumandangkan.

\section{Pengaruh Pencak Silat pada Karya Gusmiati Suid, Huriah Adam, Syofyani Bustaman, dan Syahril}

Pola dan teknik-teknik yang digunakannya Syahril mampu memberikan warna tersendiri sehingga karyanya dapat dikatakan berbeda dengan karya Gusmiati Suid, Huriah Adam, dan Syofyani Bustamam. Meskipun mereka sama-sama berangkat dari tradisi yang bersumber pada pencak silat, masing-masing tumbuh dan berkembang dengan versi dan konsep yang berbeda. Perbedaan itu dapat diamati melalui wujud gerak yang dipresentasikan dan musik pengiring yang mereka pergunakan. Gusmiati Suid lebih cenderung menggunakan vokabuler silat sebagai sumber gerak, tidak terkecuali musik yang mengiringi tariannya, juga bersumber pada musik tradisi Minangkabau seperti talempong, gendang, dan sarunai. Demikian juga karya Syahril meskipun konsepnya berangkat dari teks religious, karyanya tetap berorientasi pada teks matrilineal. Tari-tarian Syofyani dan Huriah Adam lebih mendominasi musik diatonis, seperti biola dan akordion. Hal ini tentu tidak terlepas dari latar belakang budaya yang membentuknya.

Jika diamati, keempat koreografer Minangkabau dalam merepresentasikan karyanya selalu mewariskan bakat kesenimanannya melalui keluarga inti sebagai salah satu penerus yang memegang tongkat estafet pemetaan tari Minangkabau. Meskipun demikian, transmisi yang bersifat kekeluargaan pada gilirannya mengalami transformasi di wilayah yang lebih luas. Sebagai koreografer perempuan mereka mencermati persoalan perempuan dengan caranya sendiri. Kepedulian itu nampak dalam sikap dan karyakarya yang mereka ciptakan.

\section{Perempuan dan Seni Tari}

Perempuan senatiasa memiliki pesona keindahan di tengah kehidupan masyarakat. Pesona demikian pun terjadi di dunia seni pertunjukan, seperti halnya Titim Fatimah, seorang sinden ternama di Jawa Barat, Mak Cida di tengah penyimpangan prinsip Pakarena, Elly Zuarni yang meniti seni di tengah badai Aceh, dan Gusmiyati Suid, sang pemberontak Tari Minang. Memang perempuan adalah sosok makhluk yang menarik untuk dijadikan objek dalam kehidupan berkesenian. Bahkan timbul persepsi penyajian seni yang berfungsi sebagai pertujukan dan hiburan dianggap kurang menarik jika dalam sajiannya tidak menghadirkan sosok perempuan yang secara kodrati memang sangat memesona (Caturwati, 2009:iv).

Adat Minangkabau mengajarkan bahwa perempuan adalah Limpapeh Rumah Nan Gadang, artinya perempuan itu hiasan rumah gadang, rumah adat yang diperuntukkan bagi keluarga matrilineal. Ia yang akan menghidupkan rumah itu, menggembirakan hati laki-laki jika pulang dari rantau. Sebagai perhiasan ia hanya berlaku untuk keluarga matrilinealnya. Sebagai Limpapeh Rumah Nan Gadang, ia juga bertanggung jawab membela moral keluarga matrilinealnya, sekaligus sebagai jaminan nama baik keluarga. Tanggung jawab itu diekspresikan dengan tutur kata dan tingkah laku yang sesuai dengan ajaran adat.

Sebagai ibu di Rumah Gadang, seorang perempuan berperan sebagai Bundo Kanduang, yaitu pusat pelintasan berita dan sumber kebijaksanaan bagi kaumnya. Dalam kedua peran itu perempuan memberikan rundingan kepada ninik mamak-nya. Kepada pihak luar, ninik mamak itulah yang berunding. Dapat dikatakan bahwa kata laki-laki lebih merupakan kata pemutus, sebaliknya perempuan dilindungi saudara lakilaki matrilinealnya, harta pusaka digunakan oleh perempuan dengan anak-anaknya. 
Tampaknya, perempuan memiliki peran setingkat lebih tinggi daripada laki-laki. Peran dimaksud terefleksi dalam bidang perekonomian dan moral, namun perempuan tidak diberi ruang untuk memerankan urusan-urusan publik, seperti memasuki dunia seni pertunjukan, karena dipandang tidak pantas seorang perempuan tampil di hadapan laki-laki apalagi dipertontonkan di depan publik.

Kondisi tersebut berbanding terbalik ketika melihat kegigihan perempuan Minangkabau memasuki dunia seni pertunjukan antara lain disebabkan oleh banyaknya minat generasi muda pada tahun 1980-an memasuki dunia pendidikan formal seni, yaitu ASKI Padangpanjang yang kini menjadi ISI Padangpanjang, UNP Padang, dan SMKI Padang (Astuti, 2003:98).

Empat koreogrefer Minangkabau dikenal cukup produktif dalam berkarya ditunjukkan melalui representasi karya-karya mereka yang terlibat dalam berbagai event kesenian baik yang berskala nasional maupun internasional. Koreografer dimaksud adalah generasi yang muncul dari lingkungan akademik secara tidak langsung mereka tidak hanya mengandalkan kemampuan teknis yang dimilikinya, tetapi diikuti oleh intelektualitas. Tidak heran jika mereka dikenal bahkan karya tarinya dijadikan sebagai materi ajar di berbagai perguruan tinggi seni dan sekolahsekolah Sumatera Barat (Mulyati, 2009:194).

Kepedulian mereka terhadap tari Minang dapat dibaca melalui teks matrilineal yang terangkai dalam berbagai karya mereka. Ada keinginan mengembalikan citra tari Minang ke dasar-dasar pencak silat. Kondisi ini jelas adanya bahwa karya mereka tidak dipandang dari sisi genealogis saja, tetapi dapat dilihat juga dari sudut pandang budaya, yaitu budaya patrilineal. Begitu pun sebaliknya, teks patrilinael dapat dilihat pada musik pengiring tari berorientasi pada budaya Eropa, nampaknya teks patrilineal mendominasi karya Huriah Adam dan Syoyani Yusaf. Selain itu, sebagai koreografer perempuan yang lahir dan dibesarkan dalam kultur Minangkabau justru ikut merasakan betapa dilematisnya posisi perempuan dalam masyarakat Minangkabau. Fakta bahwa keempat koreografer tersebut lahir dan besar di Minangkabau, namun kemudian berkiprah dalam tiga wilayah kultur yang berbeda. Huriah Adam di Padangpanjang, Gusmiati Suid di Jakarta, Syofyani di Padang, dan Syahril di Padangpanjang. Meskipun mereka samasama mengangkat tari Minang, masing-masing memiliki identitas dalam memandang perempuan yang kemudian direpresentasikan dalam karyakarya mereka.

Identitas pribadi seseorang yang terbentuk tidak akan lepas oleh identitas budayanya. Meskipun suatu saat ia dapat berubah dari budaya asalnya dan memasuki budaya lain, ia tetap terbebani oleh budaya asalnya. Pada dasarnya kesenian sebagai bagian dari kebudayaan inilah yang diduga kuat menjadikan kesenian di Minangkabau milik komunitas yang bersifat kekeluargaan (pewarisan budaya dalam keluarga). Hal ini ditemukan dalam koreografer Gusmiati Suid. Gusmiati Suid dan anaknya, Boy Gumarang Sakti adalah dua koreografer ibu - anak - yang saling memiliki similaritas, yaitu dua hal yang berbeda tetapi dianggap mengandung hal yang serupa. Tampaknya bakat yang dimiliki oleh ibunya mengaliri darah kesenimanan anaknya.

Dalam kaitannya dengan Minangkabau tentu fenomena ini dipegaruhi pula oleh agama Islam. Kasus keterlibatan koreografer perempuan di dunia tari menjelaskan bagaimana sikap dan kepedulian mereka terhadap tari Minangkabau. Gambaran mereka dalam dunia tari dapat dilihat sebagai bagian dari suatu gerakan kaum perempuan dalam berhadapan dengan tradisi yang mengekang perempuan di satu sisi dan modernisasi yang menawarkan emansipasi di sisi lain.

Besarnya akses perempuan Minangkabau memasuki dunia seni pertunjukan antara lain disebabkan oleh banyaknya generasi muda, khususnya perempuan, semenjak tahun 1980an yang memasuki pendidikan formal seni, yaitu ASKI Padangpanjang yang kini menjadi ISI Padangpanjang dan IKIP Padang. Dalam konteks perubahan inilah, bermunculan sejumlah koreografer perempuan Minangkabau. Para koreografer ini umumnya adalah generasi yang lahir dari lingkungan akademik yang tidak sekedar mengandalkan bakat, tetapi sekaligus kemampuan teknis dan intelektual yang dimilikinya melalui garapan tariannya. Mereka adalah perempuan- 
perempuan Minangkabau yang dibesarkan dalam tradisi keterbukaan di mana pembatasan keterlibatan perempuan tidak seketat dahulu.

\section{Simpulan}

Tinjauan dari berbagai dimensi terhadap aktivfitas dan kreativitas koreografer perempuan Minangkabau menunjukkan adanya keanekaragaman bentuk yang terjadi dalam kehidupannya. Hal ini mengindikasikan adanya proses kelangsungan dan perubahan dalam posisi kaum perempuan di Minangkabau dalam kedinamikaan sosial masyarakatnya. Dari aktivitas sosial dan didukung kreativitas mampu melahirkan karya tari sebagai entitas sosialnya yang sarat akan nilai-nilai tradisi yang berlaku dalam masyarakatnya. Kenyataan bahwa budaya yang diwariskan dari tradisi leluhurnya disertai keyakinan terhadap nilai-nilai keadatannya tertuang dalam falsafah dan pandangannya telah membentuk identitas budaya dan local genius kaum perempuan Minangkabau.

Kedinamikaan yang dimiliki koreografer perempuan dan seorang koreografer muda lakilaki telah membawa perubahan dan kedudukan serta peran kaum perempuannya sebagai pelestari budaya. Aktivitas dan kreativitas yang dimiliki oleh koreografer perempuan Minangkabau merupakan bagian historis perilaku yang pernah diwariskan oleh pendahulunya bahwa aktivitas tersebut tidak terlepas dari pola perilaku perempuan yang berpikir maju dan intelektual yang telah berjasa dalam proses perubahan dan posisi kaumnya pada masa itu sehingga memberikan peran bagi koreografer perempuan dalam kehidupan berkeseniannya.

\section{Ucapan Terima Kasih}

Rasa terima kasih disampaikan kepada Kepala Lembaga Penelitian ISI Padang Panjang yang telah memberi kesempatan kepada penulis untuk melakukan penelitian mengenai "Empat Koreografer Minang Berpengaruh" yang memungkinkan artikel ini bisa terwujud. Terima kasih juga disampaikan kepada dua mitra bebestari Resital Jurnal Seni Pertunjukan yang telah memberi komentar dan saran untuk perbaikan artikel ini.

\section{Kepustakaan}

Astuti, Pudji. 2004. Perempuan Dalam Seni Pertunjukan Minangkabau Suatu Tinjauan Genre: Yogyakarta : Kalika.

Erlinda. 2011. "Diskursus Estetika Tari Minangkabau di Kota Padang Sumatera Barat Pada Era Globalisasi” [Disertasi]. Denpasar: Universitas Udayana.

Hadi, Y. Sumandiyo. 2001. Pasang Surut Tari Klasik Gaya Yogyakarta Pembentukan dan Perkembangan. Yogyakarta Lembaga Penelitian ISI Yogyakarta.

Koentjaraningrat. 2004. Manusia Dan Kebudayaan Indonesia. Jakarta: Jambatan

Kuardhani, Hirwan. 2006. "Naskah Lakon Sabai Nan Aluih Karya Tulis Sutan Sati: Fenomena Androginik dalam Masyarakat Matrilineal Minangkabau" dalam Resital Jurnal Seni Pertunjukan. Volume 7 No. 1 Juni.

Kusmayati, Hermien. 2009. "Perempuan Dalam Seni Pertunjukan Pengawal Yang Handal" dalam Endang Caturwati (ed) Pesona Perempuan dalam Sastra dan Seni Pertunjukan . Bandung: Sunan Ambu Press.

Lynne, Hanna Yudith. 1998. "Tari sebagai media di Pendidikan Tinggi Seni" [Laporan Penelitian] Yogyakarta: Lembaga Penelitian ISI Yogyakarta.

Murgianto, Sal. 2009. "Profil Huriah Adam (19361971): Perintis Tari Minang Baru” dalam Perempuan dan Seni Pertujukan. Jakarta: Yayasan Jurnal Perempuan (YJP). 1999. "Multikulturalisme

dalam Seni Pertunjukan: Ragam Bentuk dan Motif," dalam Jurnal Seni Pertunjukan Indonesia Th IX 1998/1999.

Narawati, Tati. 2003. Wajah Tari Sunda Dari Masa Ke Masa. Bandung: Universitas Pendidikan Indonesia.

Penghulu, Dt.Radjo. 1988. Rangkaian Mustika Adat Basandi Syarak Di Minangkabau. Bandung: Rosda Karya.

Ritzer, George. 1996. Sociological Theory. New York: Mc Graww-Hill Companies, Inc.

Rustianti, Sri. 2005. "Tari Kotemporer 
Minangkabau Karya Boy Gumarang Sakti” dalam Ekspresi Jurnal Penciptaan dan Pengkajian Seni Volume 5 Nomor 1 April.

Sastra, Andar Indra. 1999. "Basaluang Dalam Bagurau: Cerminan Budaya Konflik Masyarakat Minangkabau' [Tesis]. Yogyakarta: Prodi Pengkajian Seni Pertunjukan dan Seni Rupa, Universitas Gadjah Mada , 2014. "Konsep Batalun

Dalam Talempong Renjeang Anam Salabuhan di Luhak Nan Tigo"[Disertasi]. Surakarta: Program Pascasarjana ISI Surakarta.

Sediawati, Edi. 1991. "Tari Sebagai Media Budaya: Suatu Penilaian Perkembangan di
Minangkabau" [Laporan Penelitian]. Jakarta: Direktorat Sejarah dan Nilai Tradisional bekerja sama dengan Pusat Penelitian Universitas Indonesia.

Soedarsono, RM. 2003. Seni Pertunjukan Indonesia Dari Perspektif, Poltik, Sosial Dan Ekonomi. Yogyakarta: Gama Press.

Sumartono. 2003. "Estetika Multikulturalisme dan Seni Rupa Indonesia” dalam Ekspresi Jurnal Penciptaan dan Pengkajian Seni Volume 3 No 1 April.

Suwarsono. 1991." Modern dan Modernisme dalam Seni Rupa Indonesia” Dalam Jurnal Ekspresi Seni Volume 2 No 1 April. 